\title{
EFFECTS OF $\alpha$-CHLOROHYDRIN AND RELATED COMPOUNDS ON THE REPRODUCTIVE ORGANS AND FERTILITY OF THE MALE RAT
}

\author{
E. R. A. COOPER, A. R. JONES ANd H. JACKSON \\ Unit of Reproductive Pharmacology, University of Manchester, \\ Manchester M13 9PT
}

(Received 13th August 1973)

\begin{abstract}
Summary. The antifertility effects and histopathological changes in the reproductive tract of male rats following administration of $\alpha$-chlorohydrin, $\alpha$-bromohydrin, epi-chlorohydrin and glycidol were compared. Contrary to earlier reports, $\alpha$-bromohydrin induced bilateral spermatocoeles and permanent sterility in rats but did not produce the functional epididymal sterilizing effect of $\alpha$-chlorohydrin. Glycidol reproduced the primary sterilizing effect of $\alpha$-chlorohydrin but not the lesions in the proximal caput epididymidis. Epi-chlorohydrin showed activities resembling those of $\alpha$-chlorohydrin. The primary lesion in the proximal caput epididymidis was seen specifically to involve the 'conus' and adjacent regions with sloughing of the epithelium. This may impair the secretory/absorptive function of this region with ensuing severe damage to the thin-walled ductuli efferentes. Except where granulomata were formed, restoration of the epithelium occurred. The apical region of the proximal caput remained undamaged throughout.
\end{abstract}

\section{INTRODUCTION}

Since the initial description by Ericsson (1970) of the effects of $\alpha$-chlorohydrin (3-chloropropane-1,2-diol) on the testis and epididymis of the rat, numerous studies have been undertaken with this compound in a variety of species. In the rat, low oral doses $(7$ to $8 \mathrm{mg} / \mathrm{kg}$ ) affect the fertility of spermatozoa in the cauda epididymidis (Turner, 1971) causing functional sterility, while somewhat higher doses (above $9 \mathrm{mg} / \mathrm{kg}$ ) induce histological changes in the initial segment of the caput (Gunn, Gould \& Anderson, 1969). Following a course of treatment of rats with nine doses of $15 \mathrm{mg} / \mathrm{kg} /$ day, Gunn \& Gould (1972) showed that all parts of the rat epididymis have an increased capacity selectively to concentrate zinc, which they suggest might inhibit sperm motility. High doses (e.g. 100 $\mathrm{mg} / \mathrm{kg}$ orally), however, initiate the formation of obstructive retention cysts in the ductuli efferentes and caput epididymidis (Ericsson, 1970) resulting in permanent sterility. Structure/activity studies with the $\alpha$-chlorohydrin molecule have not been successful in producing more potent derivatives and it has recently been reported that $\alpha$-bromohydrin and $\alpha$-iodohydrin did not show antifertility activity in the rat (Banik, Tanikella \& Rakhit, 1972). 
In the present study, the antifertility and histopathological effects of $\alpha$-chlorohydrin and several related compounds have been compared.

\section{MATERIALS AND METHODS}

The compounds, $\alpha$-chlorohydrin, epi-chlorohydrin (B.D.H. Chemicals Ltd) and glycidol (Aldrich Chemical Co.), were purified by distillation, while $\alpha$-bromohydrin and $\alpha$-iodohydrin were synthesized and purified by distillation and
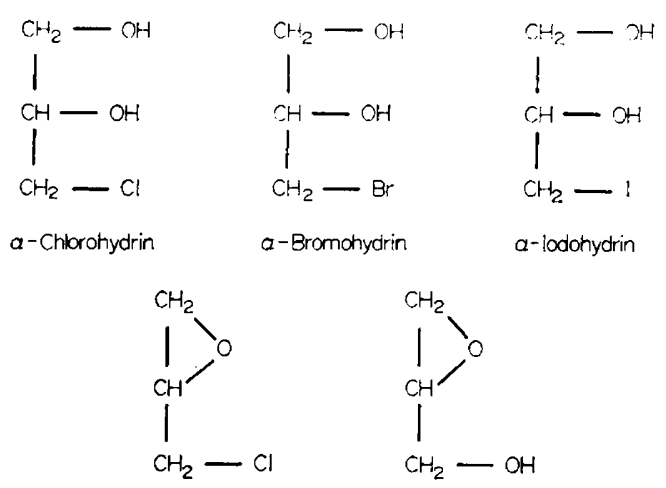

Epi- chiorohydrin

Glycidol

TEXT-FIG. 1. The formula of $\alpha$-chlorohydrin and related compounds.

recrystallization, respectively. The compounds (Text-fig. 1) were administered orally in water to adult male Wistar rats except for epi-chlorohydrin and $\alpha$-iodohydrin which were given as suspensions in arachis oil. In the histological studies, a total of 100 animals (in the weight range 280 to $320 \mathrm{~g}$ ) was examined between the following intervals after dosing: $\alpha$-chlorohydrin $(100 \mathrm{mg} / \mathrm{kg}), 18 \mathrm{hr}$ to 52 weeks; $\alpha$-bromohydrin $(100 \mathrm{mg} / \mathrm{kg}), 3 \frac{1}{2} \mathrm{hr}$ to 27 weeks and a series

\section{EXPLANATION OF PLATE 1}

Frg. 1. Ductuli efferentes (DE) joining the conus (C) of the proximal caput epididymidis in a rat (control) $\times 5$.

Inset: junction of $\mathrm{DE}$ and $\mathrm{C}$, showing $(Z)$ an actual continuation of a DE tubule (ciliated epithelium) and a conus tubule (stereo-ciliated epithelium). $\times 50$.

Frg. 2. Ductuli efferentes (DE) joining the conus (C) $18 \mathrm{hr}$ after $\alpha$-chlorohydrin $(1 \times 100$ $\mathrm{mg} / \mathrm{kg}$ ). The conus tubules are distended with spermatozoa and sloughing of the lining has occurred in the intermediate part of the proximal caput (IN) but not in the apical region (A). $\mathrm{MC}=$ middle caput. $\times 6 \cdot 5$.

Fig. 3. Longitudinal section through the rat testis-epididymis complex (control). $\mathrm{CP}=$ proximal caput; $\mathrm{DE}=$ ductuli efferentes. $\times 3.5$.

Inset: junction of $\mathrm{DE}$ and $\mathrm{CP}$ showing respective histology. $\times 50$.

Fig. 4. As Fig. 3, 9 months after $\alpha$-chlorohydrin. Fibrosis has caused extreme shrinkage of the proximal caput (CP) and ductuli efferentes $(\mathrm{DE})$. Testis aspermatic. $\times 3.5$.

Inset: Fibrosed DE. $\times 50$.

Fic. 5. As Fig. 3, 3 weeks after glycidol $(5 \times 200 \mathrm{mg} / \mathrm{kg})$. A sperm retention cyst (S) occupies much of the cauda. Note two channels of ductuli efferentes (DE). BV=blood vessels. Spermatogenesis was normal. $\times 3.5$. 
PLATE 1
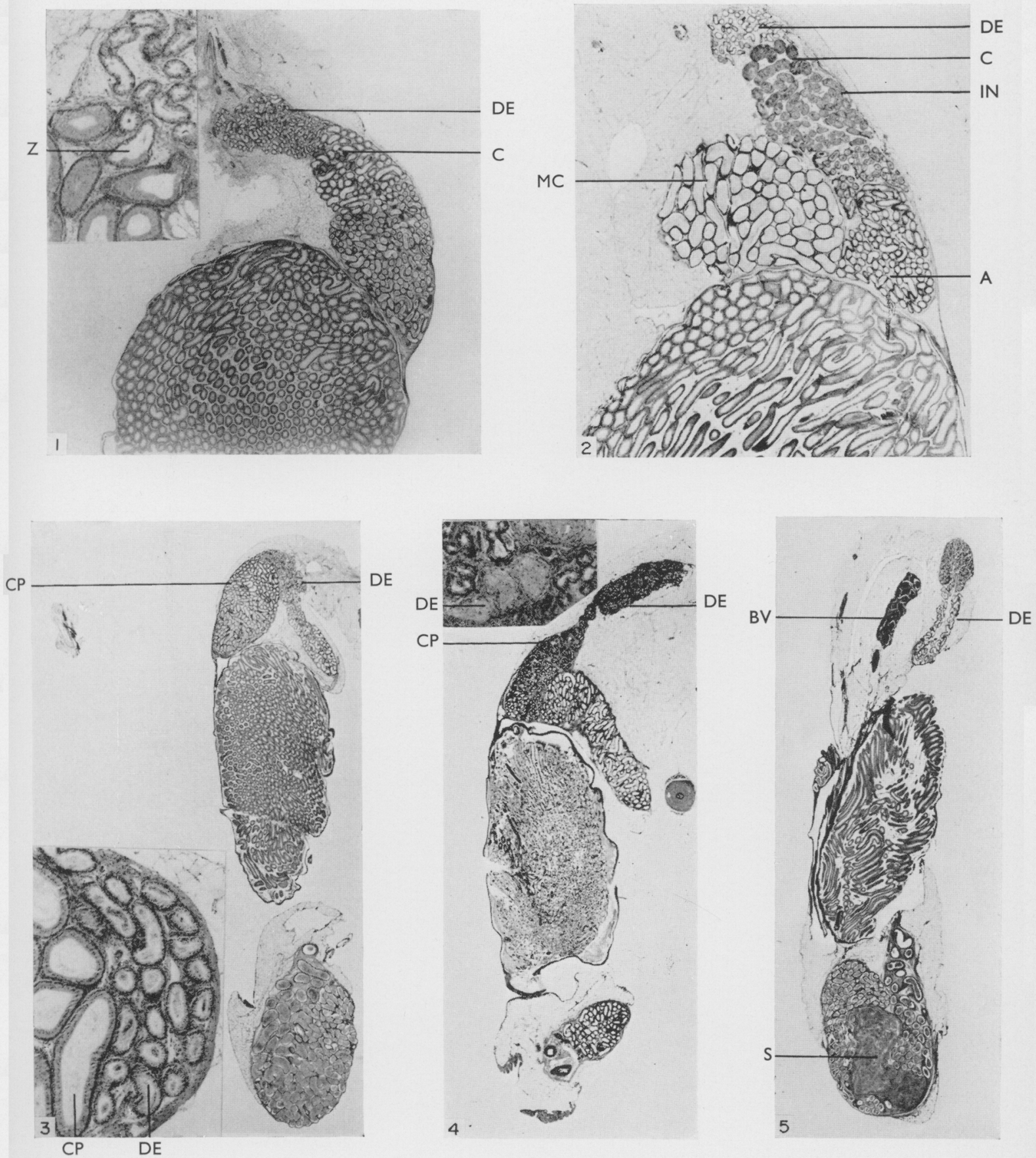
( $5 \times 100 \mathrm{mg} / \mathrm{kg})$ up to 72 weeks; $e p i$-chlorohydrin $(100 \mathrm{mg} / \mathrm{kg}), 1$ to 20 weeks; glycidol $(5 \times 200 \mathrm{mg} / \mathrm{kg}), 1$ to 12 weeks. Unilateral ligation of the ductuli efferentes was performed by the method described by Tuck, Setchell, Waites \& Young (1970) in rats anaesthetized with pentobarbitone. Ligation of the right ductuli was carried out as near as possible to their origin at the rete testis; after $4 \mathrm{hr}$, animals were given either a single oral dose of $\alpha$-chlorohydrin (100 $\mathrm{mg} / \mathrm{kg}$ ) or water and were killed $24 \mathrm{hr}$ later. For histological studies, the entire testis-epididymis-ductus deferens complex was fixed in Bouin's fluid, embedded in paraffin wax and serially sectioned in the longitudinal plane (Pl. 1, Figs 3 to 5 ).

Fertility tests were carried out on groups of five proven fertile male animals (a total of fifty-five rats) according to the method described by Bock \& Jackson (1957).

\section{RESULTS}

\section{$\alpha$-Chlorohydrin}

Towards the end of the 1st day after the dose, one or both ductuli efferentes were dilated at their origin. The 'conus' region of the proximal caput epididymidis (i.e. that receiving the combined ductuli efferentes) was greatly enlarged and distended with spermatozoa, the lining epithelium being compressed against the basement membrane (Pl. 1, Fig. 2). Beyond the conus, the epididymal tubule segments (intermediate zone) were enlarged, the lining epithelium was detached and, with the contained spermatozoa, formed a hyaline mass (Pl. 1, Fig. 2). The apical zone (Pl. 1, Fig. 2), which seems to represent the blind end of the mesonephric duct, showed typical columnar stereociliated cells remaining unaffected by the treatment. Overall, some degree of stromal cell reaction could be seen.

Definite formation of retention cysts was evident on the 2nd day with marked tissue reaction by polymorphs and macrophages. Near the origin of the ductuli efferentes, spermgranulomata had already formed due to rupture of the tubules with ensuing tissue reaction. The terminal regions of the ductuli efferentes were shrunken and empty but spermatocoeles and the granulomata occupied the conus. In some specimens, even at this time, clearance of the contents of parts of the conus and proximal caput could be discerned; as the débris disappeared, a flattened epithelial lining was revealed though in some areas only the basement membrane remained.

By Days 4 and 5, the pathological changes had extended throughout the ductuli efferentes and the proximal caput with the exception of the apical zone; tissue reaction was especially pronounced in the conus region, 'inflammatory' cells invading the tubules (Pl. 2, Fig. 6). Concurrently, the lumen of the middle and distal parts of the caput and the corpus had cleared but remained empty due to obstruction of the efferential channels.

Towards the end of the 1st week, large granulomata were present at the testicular origin of the ductuli efferentes while smaller lesions occupied segments of one or both channels during their course. Most of the proximal caput had been cleared of débris but remained empty and shrunken, whereas the conus area was still occupied by granulomata. 
Between the 3rd and 4th weeks, there was little further alteration histologically apart from an increase in size of the retention cysts near the origin of the ductuli efferentes and continued clearance of the cyst content with fibrosis in the stroma. After 6 months, the affected ductuli efferentes appeared as fibrohyalinized bodies; the fibrotic process extended to the rete testis. At this time, cyst formations were not observed in the proximal caput, although increased intertubular fibrosis compressed the tubules. The middle and distal portions of the caput, the corpus and the cauda were collapsed and empty with intact epithelium.

During the 2nd and 3rd days, the testis was enlarged, pale and tense. Histologically, the tubules became dilated, with compression of the seminiferous epithelium against the basement membrane. Despite this, spermatogenesis continued, contributing to the increase in size of the cysts. After 4 weeks, some tubules appeared distorted and aspermatogenic and at 6 months, only a few tubules in the centre of the testis were still functional. At 9 months and beyond, only Sertoli and indifferent cells remained in the tubules; throughout the entire period, the interstitial tissue appeared to be unaffected (Pl. 1, Fig. 4).

\section{$\alpha$-Bromohydrin}

By $13 \mathrm{hr}$ after the dose $(100 \mathrm{mg} / \mathrm{kg})$, the entire conus of the proximal caput was affected, the lining cells had been shed and were clumped with spermatozoa in the lumen. This degenerative process spread through the proximal region of the caput but the apical zone was unaffected. In general, the sequence of events followed the $\alpha$-chlorohydrin pattern but retention cysts were not observed until the end of the lst week and were confined to the conus (Pl. 2, Fig. 7). The ductuli efferentes were occupied by retention cysts, larger at the origin and smaller in the ascent and arch. At this time, the testis was large and tense though spermatogenesis was active. Among twenty-one animals examined, a spermatocoele was observed in the corpus epididymidis of one after 6 weeks and a similar lesion was found in the cauda of a second rat after 7 weeks (Pl. 2, Fig. 8). At this dose level, $\alpha$-bromohydrin was apparently incapable of producing permanent retention cysts in all animals. Fertility decreased somewhat after the 4th

\section{EXPLANATION OF PLATE 2}

Frg. 6. Rat tissues as in Pl. 1, Fig. 2 but 4 days after $\alpha$-chlorohydrin. Sperm retention cysts have formed; 1 , near the origin of the ductuli efferentes $(\mathrm{DE}) ; 2$, at the arch of the DE; 3, particularly in the conus of the proximal caput. Testis tubules spermatogenic although dilated. $\times 6 \cdot 5$.

Frg. 7. Sperm retention cysts and distended tubules in the conus $(C)$ of the proximal caput 14 days after $\alpha$-bromohydrin $(1 \times 100 \mathrm{mg} / \mathrm{kg})$. Compared with Fig. 6 , there was clearance of some tubules by macrophages. Testis tubules were dilated and distorted but spermatogenesis was active. $\times 13 \cdot 5$.

Fig. 8. Junction of cauda epididymidis and ductus deferens (D), $7 \frac{1}{2}$ weeks after $\alpha$-bromohydrin $(1 \times 100 \mathrm{mg} / \mathrm{kg}$ ). A typical spermatocoele (S) lies in the cauda which is filled with spermatozoa. $\times 6.5$.

Fig. 9. Ductuli efferentes and conus of proximal caput 31 days after $\alpha$-bromohydrin $(5 \times 100 \mathrm{mg} / \mathrm{kg})$. Large sperm retention cysts occupy the origin (1) of the ductuli efferentes; smaller ones appear in the ascent and arch (2). At the junction with the conus the ductuli efferentes are collapsed and empty (3), while arrested spermatozoa distend the conus $(\mathrm{C})$, but without spermatocoele formation. $\mathrm{BV}=$ blood vessels. $\times 5$. 
PLATE 2
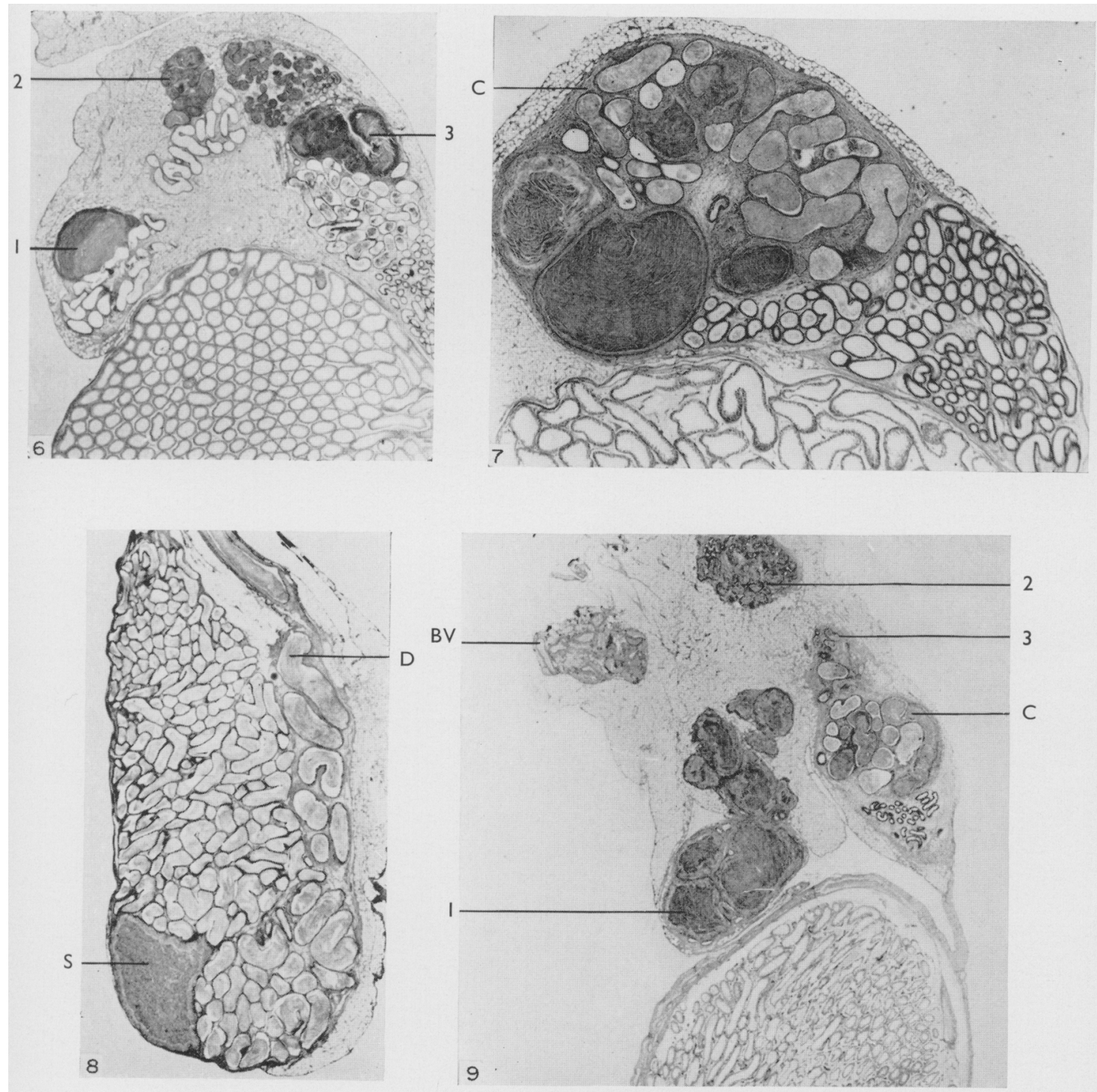
PI.ATE 3
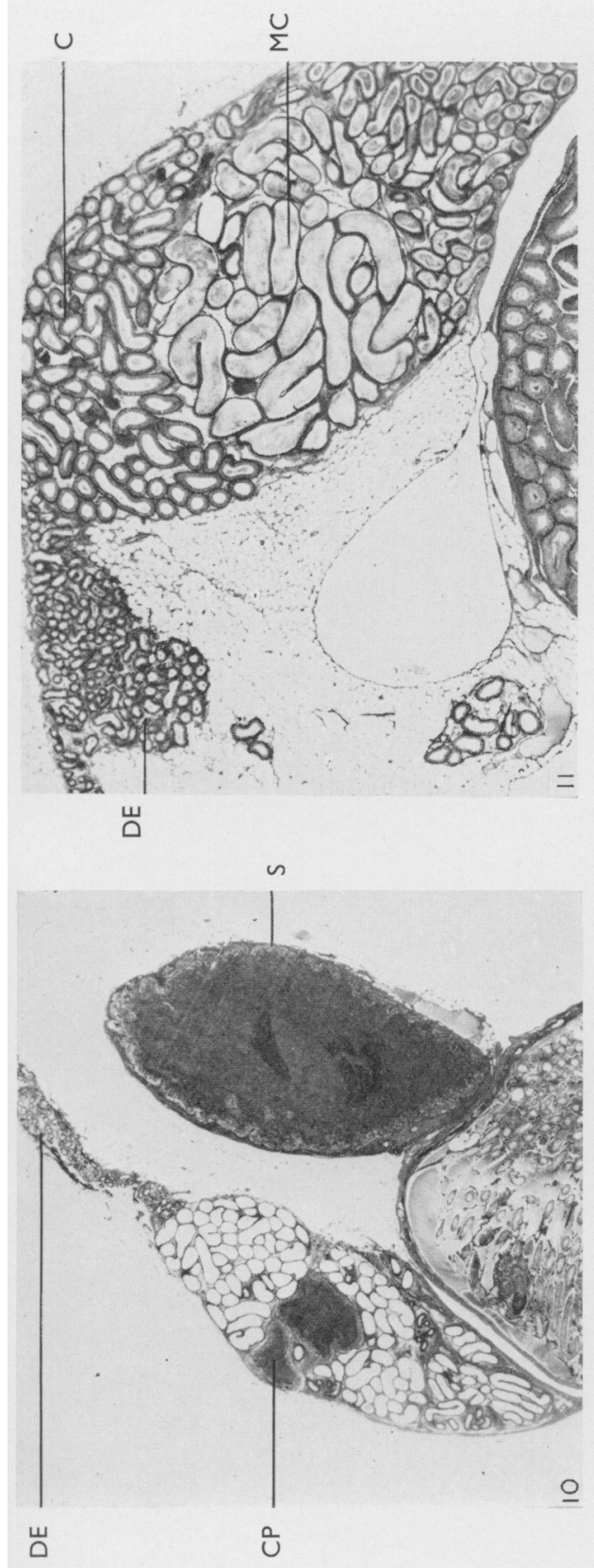
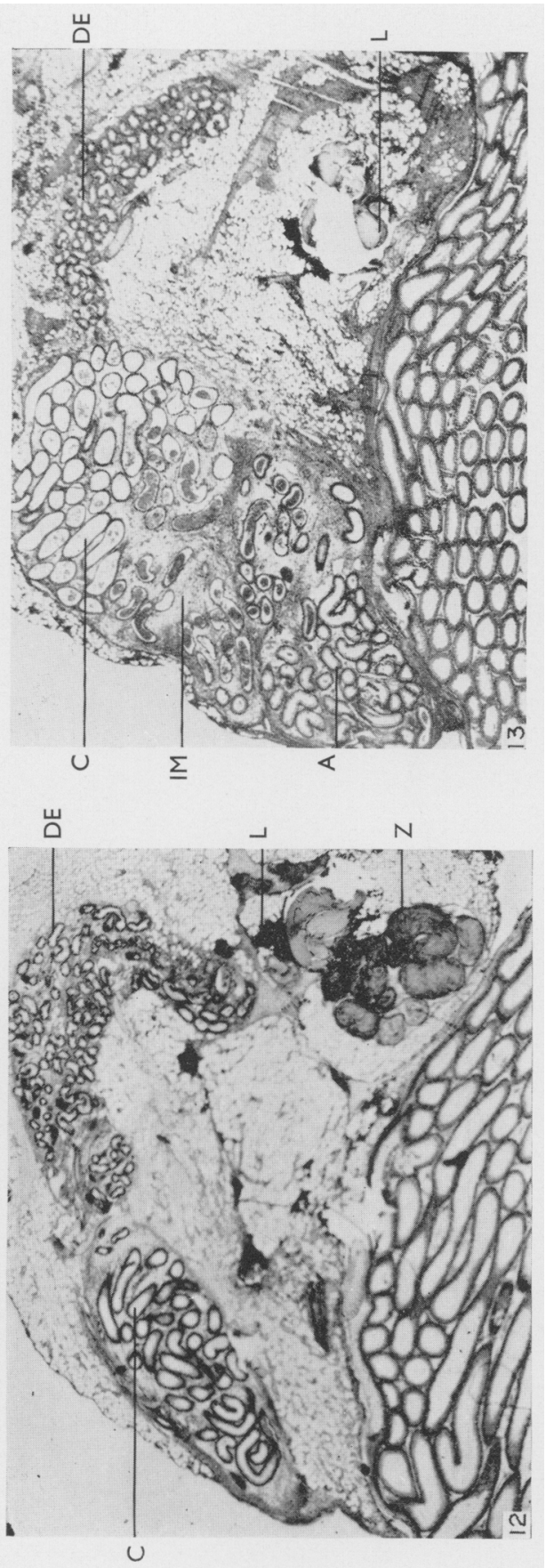
week (Table 1) due to several animals being sterile, one permanently. No initial sterile phase occurred, in contrast to the effect of $\alpha$-chlorohydrin.

After five daily doses at the above dose level, all animals were sterile in the 3rd week after treatment, emphasizing the absence of initial sterility (Table 1).

Table 1. Antifertility activity of $\alpha$-chlorohydrin and related compounds in male rats

\begin{tabular}{|c|c|c|c|c|c|c|c|c|c|c|c|c|c|}
\hline Compound & $\begin{array}{c}m g / k g \\
\text { (oral) }\end{array}$ & Weeks: & $\begin{array}{c}A v \\
1\end{array}$ & & $\begin{array}{l}e z \\
3\end{array}$ & & & litt & & & 8 & 9 & 10 \\
\hline$\alpha$-Chlorohydrin & $\begin{array}{l}5 \times 20 \\
1 \times 100\end{array}$ & & $\begin{array}{l}0 \\
0\end{array}$ & $\begin{array}{l}0 \\
0\end{array}$ & $\begin{array}{l}7 \\
0\end{array}$ & 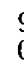 & & $\begin{array}{l}3 \\
0\end{array}$ & $\overline{0}$ & 0 & 0 & 0 & 0 \\
\hline$\alpha$-Bromohydrin & $\begin{array}{l}1 \times 100 \\
5 \times 100\end{array}$ & & $\begin{array}{l}9 \\
4\end{array}$ & $\begin{array}{l}7 \\
3\end{array}$ & $\begin{array}{l}6 \\
4\end{array}$ & 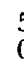 & & $\begin{array}{l}3 \\
0\end{array}$ & 0 & $\begin{array}{l}7 \\
0\end{array}$ & $\begin{array}{l}7 \\
0\end{array}$ & $\begin{array}{l}4 \\
0\end{array}$ & $\begin{array}{l}4 \\
0\end{array}$ \\
\hline Epi-chlorohydrin & $\begin{array}{l}5 \times 20 \\
5 \times 50 \\
1 \times 100\end{array}$ & & $\begin{array}{l}0 \\
0 \\
0\end{array}$ & 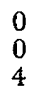 & 0 & 11 & & 1. & $\begin{array}{l}0 \\
2\end{array}$ & $\begin{array}{l}0 \\
2\end{array}$ & $\begin{array}{l}0 \\
4\end{array}$ & $\begin{array}{l}0 \\
2\end{array}$ & $\begin{array}{l}0 \\
3\end{array}$ \\
\hline Glycidol & $\begin{array}{r}5 \times 100 \\
5 \times 200 \\
14 \times 100\end{array}$ & & $\begin{array}{l}0 \\
0 \\
0\end{array}$ & $\begin{array}{l}0 \\
0\end{array}$ & $\begin{array}{l}4 \\
0 \\
0\end{array}$ & c & & 1 & 10 & 10 & 10 & 6 & 8 \\
\hline$\alpha$-Iodohydrin & $5 \times 125$ & & 4 & 5 & 4 & s & & b & 7 & 6 & 7 & 3 & 7 \\
\hline
\end{tabular}

* Five treated male rats at each dose level.

Within 8 days from the first dose, spermatocoeles, which became large and confluent, had developed in the ductuli efferentes. By Day 31, large confluent sperm retention cysts occupied the origin of the ductuli efferentes near the testis and small ones involved the rest of the ductuli. The cysts in the proximal caput remained small and clearance there was noticeable (Pl. 2, Fig. 9). Eventually (72 weeks), fibrosis of the ductuli efferentes had supervened whilst the testis tubules were shrunken and aspermatogenic.

\section{Epi-chlorohydrin}

A short oral course of epi-chlorohydrin $(5 \times 50 \mathrm{mg} / \mathrm{kg})$ affected rat fertility in a similar manner to a single large dose of $\alpha$-chlorohydrin (Table 1), although

\section{EXPLANATION OF PLATE 3}

F1G. 10. Rat tissues 12 weeks after epi-chlorohydrin $(1 \times 100 \mathrm{mg} / \mathrm{kg})$; a large spermgranuloma (S) occupies the origin and ascent of the ductuli efferentes. The rest of the ductuli efferentes (DE) are shrunken and fibrosed. Other retention cysts are present in the middle of the proximal caput (CP). Note the degenerative condition of the testis. $\times 6.5$. Fig. 11. Ductuli efferentes (DE) joining the conus (C) of the proximal caput. Control to tissues in Figs 12 and 13. $\mathrm{MC}=$ middle caput. $\times 11.5$.

Fig. 12. Ductuli efferentes (DE) and conus (C) of proximal caput $24 \mathrm{hr}$ after ligation of the ductuli efferentes near their origin. $\mathrm{L}=$ ligation site. $\mathrm{Z}=$ ductuli efferentes proximal to $L$, very distended with spermatozoa. The ductuli distal to the ligation site, and the tubules of the conus appear to be unaffected. $\times 11.5$.

FIG. 13. Ductuli efferentes (DE) and conus (C) of proximal caput $24 \mathrm{hr}$ after ligation (L) of the ductuli and $20 \mathrm{hr}$ after $\alpha$-chlorohydrin. Compared with the control (Fig. 11), sloughing of the lining epithelium of the conus (C) is evident. Collapse of sloughed tubules and oedema is seen in the middle part (IM) of the proximal caput, while the apical region $(A)$ is unaffected. $\times 11.5$. 
the single dose of the epi-compound did not elicit a similar degree of response. Histologically, no effects were apparent up to 8 weeks from a dose of $100 \mathrm{mg} / \mathrm{kg}$, apart from small spermatocoeles in the ductuli efferentes, and fertility was low (Table 1). By 12 weeks, large retention cysts were present in the ductuli efferentes and the proximal caput in four of the five test animals, which were sterile (Pl. 3, Fig. 10).

\section{Glycidol}

Single oral doses of glycidol $(200 \mathrm{mg} / \mathrm{kg})$ had no adverse effect on rat fertility or upon the histological appearance of the testis and its ducts. After five daily doses $(200 \mathrm{mg} / \mathrm{kg})$, animals were sterile for 3 weeks, although there was no discernible histological change. In one animal, a large spermatocoele occupied the cauda epididymidis (Pl. 1, Fig. 5) and in another, a small spermatocoele was seen after 5 weeks in one ductulus efferens near its origin. Normal spermatogenic activity was evident in the testes at both 5 and 8 weeks and the epididymides were filled with spermatozoa, consistent with the normal fertility observed. More prolonged treatment failed to produce sustained adverse effects on fertility and the histological appearance was normal.

\section{$\alpha$-Iodohydrin}

At the maximum tolerated level $(5 \times 125 \mathrm{mg} / \mathrm{kg}), \alpha$-iodohydrin had no effect on male rat fertility. At autopsy, 13 weeks after treatment, no spermatocoeles were seen and the ductus deferens contained motile spermatozoa.

\section{DISCUSSION}

Chemically induced spermatocoeles have been described in the epididymal pathway of the rat following administration of two compounds; ethane-1,2dimethanesulphonate (EDS) (Cooper \& Jackson, 1970, 1973) and $\alpha$-chlorohydrin (Ericsson \& Baker, 1970; Ericsson, 1971). Spermatocoeles induced by EDS may occur anywhere in the epididymal pathway whereas those produced by $\alpha$-chlorohydrin are bilateral and specifically involve the conus region of the proximal caput epididymidis and ductuli efferentes.

In the longitudinal serial sections examined in this study, the initial lesions after $\alpha$-chlorohydrin were seen to involve the junctional region of the ductuli efferentes and caput epididymidis (referred to as the conus). The specific site of the damage suggests an association with a selective physiological function of this region. According to Crabo (1965), 99\% of fluid originating from the bull and boar testis is absorbed by the caput epididymidis while the caput and corpus are known to produce a further secretion which presumably assists in the transport and nutrition of the contained spermatozoa. In turn, ligation experiments indicate that reabsorption of this fluid occurs in the cauda epididymidis (MacMillan, 1954), thus completing an endogenous circulation of fluid through the epididymis. If $\alpha$-chlorohydrin and its effective analogues interfere with the fluid dynamics of the ductuli efferentes and the proximal caput, preventing either the absorption of testicular fluid or the production of epididymal secretion, it seems to us that the pathological events described would 
follow. Accumulation of sperm-laden fluid in the thin-walled ductuli efferentes would lead to progressive distension and rupture, forming coalescing spermatocoeles and spermgranulomata, respectively. Although repair processes speedily commence in the proximal caput, as with EDS-induced lesions (Cooper \& Jackson, 1973), the granulomatous changes in the ductuli efferentes result in an inflammatory-type response with eventual fibrosis, permanent blockage of the pathway and sterility.

It has been shown that ${ }^{14} \mathrm{C}$-labelled $\alpha$-chlorohydrin, $\alpha$-bromohydrin and glycidol rapidly enter the testis within 10 min of intraperitoneal administration and appear in the rete testis fluid at levels comparable to those attained in the blood (E. M. Edwards, A. R. Jones and G. M. H. Waites, unpublished data). Thus, all three compounds have ready access to the entire spermatogenic complex and could also reach the epididymis by this route. Since the pathological changes occurring in the proximal caput are evident within $24 \mathrm{hr}$ after administration of $\alpha$-chlorohydrin, it was of interest to assess the histopathological damage following ligation of the ductuli efferentes alone, and the result of subsequent administration of $\alpha$-chlorohydrin. In animals $24 \mathrm{hr}$ after the surgical procedure only, the ductuli efferentes proximal to the ligature were greatly distended with spermatozoa whilst those distal to the site, including the proximal caput, were collapsed and empty (Pl. 3, Figs 11 and 12). Ligation followed by administration of $\alpha$-chlorohydrin did not lead to cystic changes in the proximal caput $24 \mathrm{hr}$ later. The initial tubule sections of the conus region were dilated, denuded of their lining and contained débris while sloughed cells and arrested spermatozoa were apparent throughout the rest of the proximal caput (Pl. 3, Figs 11 and 13). These changes resemble those occurring in the non-ligated animal, so that evidently sufficient blood-borne $\alpha$-chlorohydrin reaches the epididymis to induce the epithelial damage. These findings suggest that the pharmacological action of $\alpha$-chlorohydrin involves interference with an absorptive rôle of the conus region.

From their examination of many analogues of $\alpha$-chlorohydrin, Ericsson \& Youngdale (1970a) concluded that the chlorohydrin moiety was an essential component for antifertility activity although its presence did not necessarily confer this property. Although Banik et al. (1972) reported that $\alpha$-bromohydrin was inactive in the rat at low dose levels ( 5 to $8 \mathrm{mg} / \mathrm{kg}$ ), the present study has shown that epi-chlorohydrin and high doses of $\alpha$-bromohydrin produce comparable retention cysts in the rat, leading ultimately to permanent sterility. The predominant action of $\alpha$-chlorohydrin, the functional sterilization of epididymal spermatozoa, does not occur with the bromo-compound (Table 1). Glycidol was proposed as an active intermediate responsible for the temporary sterilizing action of $\alpha$-chlorohydrin (Jackson, Campbell \& Jones, 1970) although Ericsson $\&$ Youngdale (1970b) consider that glycidol may be converted to $\alpha$-chlorohydrin in the rat stomach. In the rat, glycidol does not produce permanent sterility even after prolonged high dosage (Table 1) and in the minority of animals in which small retention cysts do form, they are readily recanalized and appear to resolve completely. Dehydrobromination of $\alpha$-bromohydrin readily occurs in vivo and could produce glycidol but even from high doses of the bromo-compound levels of the epoxide may be too low to be effective. Similar 
reasons might account for the inactivity of $\alpha$-iodohydrin. The metabolic pathway of epi-chlorohydrin (Jones, Davies, Edwards \& Jackson, 1969) indicates that this compound is hydrolysed in vivo to $\alpha$-chlorohydrin, which would explain the similarity of their antifertility effects. It is undecided whether a common intermediate is involved which may be active directly on spermatozoa.

\section{REFERENCES}

Banik, U. K., Tanikella, T. \& Rakhit, S. (1972) Oral antifertility effects of halopropanediol derivatives in male rats. $\mathcal{F}$. Reprod. Fert. 30, 117.

Bock, M. \& JAckson, H. (1957) The action of triethylenemelamine on the fertility of male rats. $\mathrm{Br}$. 7. Pharmac. Chemother. 12, 1.

Cooper, E. R. A. \& Jackson, H. (1970) Comparative effects of methylene, ethylene and propylene dimethanesulphonates on the male rat reproductive system. F. Reprod. Fert. 23, 103.

Cooper, E. R. A. \& Jackson, H. (1973) Chemically induced sperm retention cysts in the rat. 7 . Reprod. Fert. 34, 445.

Grabo, B. (1965) Studies on the composition of epididymal content in bulls and boars. Acta vet. scand. 6, Suppl. 5.

Ericsson, R. J. (1970) Male antifertility compounds: U-5897 as a rat chemosterilant. F. Reprod. Fert. $22,213$.

ERIcsson, R. J. (1971) Antispermatogenic properties of 2,3-dihydro-2-(1-naphthyl)-4(1H)-quinazolinone (U-29409) (35,614). Proc. Soc. exp. Biol. Med. 137, 532.

ERIcsson, R. J. \& BAKER, V. F. (1970) Male antifertility compounds: biological properties of U-5897 and U-15,646. F. Reprod. Fert. 21, 267.

Ericsson, R. J. \& Youngdale, G. A. (1970a) Male antifertility compounds: structure and activity relationships of U-5897 and U-15,646 and related substances. J. Reprod. Fert. 21, 263.

Ericsson, R. J. \& Youngdale, G. A. (1970b) Nature, Lond. 226, 386.

Gunn, S. A. \& Gould, T. C. (1972) The role of zinc in the post-testicular antifertility action of monochlorhydrin. Proc. Soc. exp. Biol. Med. 141, 639.

Gunn, S. A., Gould, T. G. \& Anderson, W. A. D. (1969) Possible mechanism of post-testicular antifertility action of 3-chloro-1,2-propane-diol. Proc. Soc. exp. Biol. Med. 132, 656.

Jackson, H., Campbell, I. S. C. \& Jones, A. R. (1970) Is glycidol an active intermediate in the antifertility action of $\alpha$-chlorhydrin in male rats? Nature, Lond. 226, 86.

Jones, A. R., Davies, P., Edwards, K. \& Jackson, H. (1969) Antifertility effects and metabolism of $\alpha$ - and epi-chlorhydrins in the rat. Nature, Lond. 224, 83.

MacMrllan, E. W. (1954) Observations on the isolated vaso-epididymal loop and on the effects of experimental subcapital epididymal obstructions. Stud. Fert. 6, 57.

Tuck, R. R., Setchell, B. P., Waites, G. M. H. \& Young, J. A. (1970) The composition of fluid collected by micropuncture and catheterisation from the seminiferous tubules and rete testis of rats. Pflügers Arch. ges. Physiol. 318, 225.

TURNER, M. A. (1971) Effects of $\alpha$-chlorhydrin upon the fertility of spermatozoa of the cauda epididymidis of the rat. 7. Reprod. Fert. 24, 267. 